\title{
PENGEMBANGAN MODEL FUNGSI SOSIAL BISNIS ISLAM BERDASARKAN MAQASHID SYARIAH PADA BANK SYARIAH $X$
}

\author{
Muhamad Nafik H. R. ${ }^{1)}$ \\ R. Moh. Qudsi Fauzy ${ }^{2}$ \\ ${ }^{1)}$ Fakultas Ekonomi dan Bisnis, Universitas Airlangga \\ e-mail: manhard999@yahoo.com \\ ${ }^{2)}$ Fakultas Ekonomi dan Bisnis, Universitas Airlangga \\ e-mail: qudsifauzy@gmail.com
}

\begin{abstract}
The purpose of this study was to determine the concept of the social function of business model development Islam, especially Islamic Bank X based maqashid sharia, practice development of the social functions of Islamic business models based on the sharia maqashid Islamic Bank $X$, and the impact of the development of the social functions of Islamic business models based on the quality of sharia maqashid life of the community. This study uses descriptive qualitative research methodology case study method (case study). Criteria informant was branch manager, supervisor, and citizens who have been the target/target activities of social function. The sampling technique is done with purposive sampling and snowball sampling. These results indicate that the concept of the social function of business model development Islam, especially Islamic Bank X based maqashid sharia has had an important role in creating justice and prosperity based on the principles of Shari'ah maqashid especially the external community. Practice development of the social function of the business model of Islam based on sharia maqashid has had a big role in terms of fighting and reduce disorientation in religion (hifdhud-din), the maintenance of stupidity (hifdhul-'aqal), terjauhkannya of poverty (hifdhul maal), has a good offspring (hifdhun-nasl), and maintaining a healthy soul (hifhdun-nafs), and the impact of the development of the social function of the business model of Islamic sharia maqashid based not only on improving the quality of life of citizens around the location of Bank Syariah X which has a weak economy, but also an impact positively to the image of the Islamic Bank X in the minds of customers and other parts of society.
\end{abstract}

Keyword: social function, Maqashid Syariah

\section{PENDAHULUAN}

Pada hakekatnya perusahaan memang memiliki dua fungsi, yaitu fungsi bisnis dan fungsi sosial. Fungsi bisnis suatu perusahaan adalah memperoleh laba (profit) melalui usaha yang dijalankan, sedangkan fungsi sosialnya adalah memberikan manfaat kepada lingkungan sekitar dengan cara meningkatkan kualitas kehidupan masyarakatnya sebagai bentuk tanggung jawab kepada Allah SWT, masyarakat, dan lingkungan (Ryandono, 2011).

Nabi Muhammad SAW pernah bersabda:

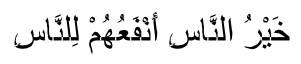

"Sebaik-baik manusia adalah yang mulia akhlaqnya dan bermanfaat bagi manusia yang lain“". 
Fungsi sosial atau yang oleh masyarakat disebut dengan tanggung jawab sosial $(\mathrm{CSR}=$ Corporate Social Responsibility) pertama kali diperkenalkan oleh Bowen dalam tulisannya yang berjudul Social Responsibility of the Business men pada tahun 1953, tanggung jawab sosial yang dimaksud oleh Bowen mengarah kepada kewajiban pelaku bisnis untuk membuat dan melaksanakan kebijakan, keputusan, dan berbagai tindakan yang harus mengikuti tujuan dan nilai-nilai dalam suatu masyarakat (Wahyudi dan Azheri, 2008c). Selanjutnya, dalam teori pemasaran Islam, istilah CSR disebut dengan fungsi sosial, hal ini disebabkan istilah CSR berasal dari kaum Nasrani.

Fungsi sosial bagi orang yang mampu/perusahaan telah diperintahkan oleh Allah SWT sebagaimana tercantum dalam QS Al Qashash: 77

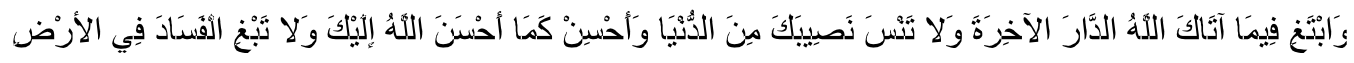

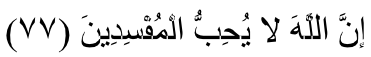

"dan carilah pada apa yang telah dianugerahkan Allah kepadamu (kebahagiaan) negeri akhirat, dan janganlah kamu melupakan bahagianmu dari (kenikmatan) duniawi dan berbuat baiklah (kepada orang lain) sebagaimana Allah telah berbuat baik, kepadamu, dan janganlah kamu berbuat kerusakan di (muka) bumi. Sesungguhnya Allah tidak menyukai orang-orang yang berbuat kerusakan”.

Pada tahun 2009 lalu, perbankan syariah di Indonesia bersinergi mencanangkan Islamic Banking Corporate Social Responsibility (IB-CSR) dengan total pembiayaan senilai Rp 1,450 miliar. IB CSR ini akan menyalurkan dananya kepada yang berhak dengan komposisi 50\% untuk pengusaha ekonomi mikro lewat dana bergulir, 25\% untuk sektor pendidikan, dan $25 \%$ untuk bantuan bencana alam. Berdasarkan dari pengumpulan dana melalui tiga sektor tersebut maka akan disisihkan 2,5\% untuk dana promosi tahun 2010 (www.bataviase.co.id). Namun, jika dikaitkan dengan konsep maqashid syariah, apakah betul-betul penyaluran dana oleh bank syariah selama ini telah memenuhi maqashid syariah. Maqashid al-Syariah di kalangan ulama ushul fiqih disebut juga dengan asrar al-syariah, yaitu rahasia-rahasia yang terdapat di balik hukum yang ditetapkan oleh syara', berupa kemaslahatan umat manusia baik di dunia maupun akhirat (Salihima, 2010). Menurut Imam Al-Ghazali, al-maqhsud syariah adalah untuk menciptakan kesejahteraan manusia dunia akhirat, individu, dan sosial yang terletak pada 5 dasar (Chapra, 2000): Menjamin din, menjaga nafs, mendorong 'aql, menjamin nasl, dan menjamin maal. Dengan demikian, menjadi penting untuk melakukan penelitian ini yang akan mengeksplorasi pengembangan model fungsi sosial bisnis Islam berdasarkan maqashid syariah pada Bank Syariah X di Surabaya.

\section{KAJIAN TEORI}

\section{Perintah Melaksanakan Fungsi Sosial}

Fungsi sosial bagi orang yang mampu/perusahaan telah diperintahkan oleh Allah SWT sebagaimana tercantum dalam QS Al Qashash: 77

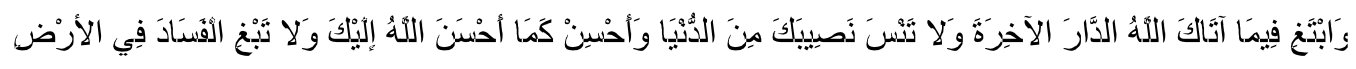

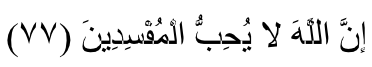


"dan carilah pada apa yang telah dianugerahkan Allah kepadamu (kebahagiaan) negeri akhirat, dan janganlah kamu melupakan bahagianmu dari (kenikmatan) duniawi dan berbuat baiklah (kepada orang lain) sebagaimana Allah telah berbuat baik, kepadamu, dan janganlah kamu berbuat kerusakan di (muka) bumi. Sesungguhnya Allah tidak menyukai orang-orang yang berbuat kerusakan”.

Menurut Shihab (2010) dalam kitabnya, Tafsir Al-Mishbah, menyatakan bahwa beberapa orang dari kaum Nabi Musa As itu melanjutkan nasihatnya kepada Qarun bahwa nasihat ini bukan berarti engkau hanya boleh beribadah murni dan melarangmu memperhatikan dunia. Ayat ini menuntun manusia untuk berusaha sekuat tenaga dan pikiran dalam batas yang dibenarkan Allah untuk memperoleh harta dan hiasan duniawi dan carilah secara sungguh-sungguh pada, yakni melalui apa yang telah dianugerahkan Allah kepadamu dari hasil usahamu itu kebahagiaan negeri akhirat, dengan menginfaqkan dan menggunakannya sesuai petunjuk Allah dan dalam saat yang sama janganlah melupakan, yakni mengabaikan, bagianmu dari kenikmatan dunia dan berbuat baiklah kepada semua pihak, sebagaimana atau disebabkan karena Allah telah berbuat baik kepadamu dengan aneka nikmat-Nya, dan janganlah engkau berbuat kerusakan dalam bentuk apapun di bagian manapun di bumi ini. Sesungguhnya Allah tidak menyukai para pembuat kerusakan.

Selanjutnya, Shihab (2010) mengatakan bahwa kata (اميف) fiimaa dipahami oleh Ibn 'Asyuur mengandung makna terbanyak atau pada umumnya, sekaligus melukiskan tertancapnya ke dalam lubuk hati upaya mencari kebahagiaan ukhrawi melalui apa yang dianugerahkan Allah dalam kehidupan dunia ini. Hal ini juga dipertegas pada firman-

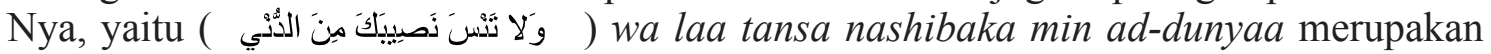
larangan melupakan atau mengabaikan bagian seseorang dari kenikmatan duniawi.

\section{Perbedaan Corporate Social Responsibility (CSR) dengan Fungsi Sosial}

Terdapat dua perbedaan secara signifikan antara CSR dengan Fungsi Sosial, yaitu (Ratnasari, 2013):

1. Corporate Social Responsibility (CSR)

Sejarah kemunculan CSR dimulai dari:

a. Akhir abad ke-19: Perusahaan-perusahaan besar menyalahgunakan kuasa mereka dalam hal diskriminasi harga, menahan buruh dan perilaku lainnya yang menyalahi moral kemanusiaan.

b. Menurut Mohr et.al. dalam Dean (2004), CSR adalah komitmen perusahaan untuk mengeliminasi atau meminimalkan setiap efek berbahaya (harmful effects) dalam masyarakat dan memaksimalkan keuntungan jangka panjang. Dengan demikian, tujuan aktifitas CSR adalah orientasi duniawi, yaitu untuk kelangsungan hidup perusahaan.

2. Fungsi Sosial

a. Perintah untuk melaksanakan fungsi sosial berasal dari firman Allah SWT, yaitu seperti yang telah dijelaskan pada nash Al-Qur'an surat Al-Qashash ayat 77, di mana Al-Qur'an telah diturunkan kepada Nabi Muhammad saw 1500 tahun yang lampau.

b. Tujuan dilaksanakan fungsi sosial adalah sebagai bentuk penghambaan kepada Rab-nya manusia (Allah SWT), yang merupakan bentuk pertanggungjawaban manusia/hamba Allah SWT yang telah memiliki harta berkecukupan untuk 
bersedia berbagi kebahagiaan dengan orang lain agar kehidupannya bisa mencapai idrak shilah billah (kedekatan hubungannya dengan Allah SWT karena mendapatkan ridho-Nya).

\section{Definisi Fungsi Sosial Bisnis Islam}

Prastowo dan Huda (2011) menyatakan bahwa fungsi sosial adalah bagian dari aktivitas sedekah. Sedekah dalam arti normatif, yakni menyisihkan sebagian hartanya untuk kepentingan umat manusia yang lain, sehingga hukum mukjizat sedekah pun juga berlaku pada fungsi sosial. Sebesar apapun dana yang dikeluarkan untuk fungsi sosial, tidak akan mengurangi harta perusahaan karena pintu-pintu keuntungan akan dibuka selebar-lebarnya oleh Allah SWT.

Hal ini tertuang dalam al-Qur'an surat al An'am ayat 160

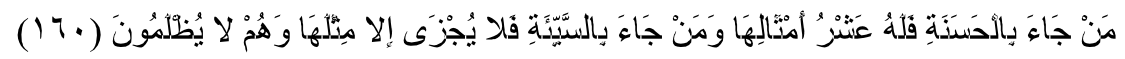

"Barangsiapa membawa amal yang baik, Maka baginya (pahala) sepuluh kali lipat amalnya; dan barangsiapa yang membawa perbuatan jahat Maka dia tidak diberi pembalasan melainkan seimbang dengan kejahatannya, sedang mereka sedikitpun tidak dianiaya (dirugikan)".

\section{Definisi Maqashid Syariah}

Maqhasid adalah bentuk plural dari kata maqshid yang dalam hal ini berarti makna atau tujuan. Sedangkan syari'at adalah sesuatu ketentuan hukum yang disyari'atkan Allah SWT terhadap hamba-Nya agar dengan tuntunan syari' at hamba-Nya mendapatkan petunjuk, atau dengan ungkapan lain syari'at adalah suatu ketentuan hukum yang terangkum dalam Al-Qur'an dan Al-Hadits. Menurut Imam Al-Ghazali, al-maqhsud syariah adalah untuk menciptakan kesejahteraan manusia dunia akhirat, individu, dan sosial yang terletak pada 5 dasar (Chapra, 2000):

1. Menjamin hidupnya akidah, iman dan keyakinan yang benar (din)

2. Menjaga keberadaan dan peran diri (nafsu)

3. Mendorong dan menghidupkan pemanfaatan dan kebebasan berpendapat atau intelektual (aql)

4. Menjamin langgengnya generasi penerus (nasl)

5. Menjamin pemilikan kekayaan (mal).

\section{Pengembangan Model Fungsi Sosial Bisnis Islam Berdasarkan Maqashid Syariah}

Prastowo dan Huda (2011) menyatakan bahwa aktivitas fungsi sosial yang paling utama adalah dengan memberikan pemberdayaan masyarakat secara Islami, di mana pemberdayaan masyarakat ini akan dapat menciptakan mekanisme bantuan sosial yang mengutamakan kemampuan/keberdayaan dan kekuasaan masyarakat. Hal ini dimaksudkan untuk mengimplementasikan hadits yang diriwayatkan oleh Bukhari yang artinya: "Tangan diatas lebih baik daripada tangan di bawah".

Muslim (2009) memberikan rincian terkait dengan pemberdayaan masyarakat secara Islami, yaitu meliputi:

1. Perubahan yang dimulai dari diri sendiri.

Perubahan yang dimulai dari diri sendiri menjadi prinsip dasar dari pemberdayaan masyarakat. Hal ini sesuai dengan firman Allah SWT dalam QS. Ar-Ra'du: 11 
2. Perubahan mengarah kepada perbaikan hidup.

Hal ini sesuai dengan hadits yang disampaikan oleh Bukhari dan Muslim, yang artinya:

"Barangsiapa yang hari ini lebih baik daripada hari kemarin maka dia adalah orang yang beruntung, sedangkan orang yang hari ini sama dengan hari kemarin atau lebih jelek dari hari kemarin maka dia termasuk orang yang merugi”.

\section{Rancangan Penelitian}

Penelitian ini menggunakan metodologi penelitian kualitatif deskriptif dengan metode studi kasus (case study). Penelitian studi kasus merupakan strategi yang sesuai dengan pertanyaan dari penelitian bila pokok pertanyaannya berkenaan dengan "bagaimanakah" dan "mengapa" (Yin, 2008).

\section{Kriteria Informan}

Untuk memperoleh informasi mengenai bagaimana implementasi fungsi sosial perspektif maqashid syariah pada Bank Syariah X di Surabaya, maka dalam penelitian ini ditetapkan kepala cabang, supervisor, dan warga masyarakat sebagai informan dengan kriteria sebagai berikut:

1. Kepala Kantor Cabang yang telah menduduki posisi jabatannya minimal satu tahun pada Bank Syariah X di Surabaya.

2. Bagian Operasional yang telah menduduki posisi jabatannya minimal satu tahun pada Bank Syariah X di Surabaya.

3. Warga masyarakat (6 orang) yang telah menjadi target/sasaran aktifitas fungsi sosial dari Bank Syariah X di Surabaya.

\section{Teknik Pengambilan Sampel}

Sugiyono (2010) mengatakan bahwa teknik pengambilan sampel dalam penelitian kualitatif dapat dilakukan dengan purposive dan snowball sampling, teknik pengumpulan data melalui triangulasi, analisis data bersifat induktif, dan hasil penelitian lebih menekankan makna daripada geralisasi. Dengan demikian, dalam penelitian ini, teknik pengambilan sampel dilakukan dengan purposive sampling dan snowball sampling, di mana informan dipilih sesuai dengan tujuan dan kriteria yang dimaksud oleh peneliti.

\section{ANALISIS DAN PEMBAHASAN}

Nafik (2010) menjelaskan bahwa motivasi utama aktivitas bank Islam adalah tolong menolong dan kemitraan. Berkaitan motif bank Islam ini, Qureshi (1946) berpendapat bahwa,

"Bank merupakan sebuah pelayanan sosial yang disponsori oleh pemerintah seperti pendidikan dan kesehatan publik. Ia mengambil titik pandang ini semenjak bank tidak akan membayar bunga baik kepada pemegang rekening maupun tidak memberi beban bunga pada pinjaman. Qureshi juga membicarakan kemitraan antara bank dan pengusaha sebagai sebuah alternatif yang memungkinkan, bagi untung dan bagi rugi jika ada kerugian."

Walaupun bank Islam motifnya kemitraan dan tolong menolong, tetapi dalam operasionalnya tidak boleh mengesampingkan orientasi untuk mencari keuntungan. 
Motif mencari keuntungan tidak bertentangan dengan ajaran Islam bahkan umat Islam diperintahhan untuk mencari keuntungan yang besar tidak hanya di dunia saja melainkan juga keuntungan akhirat kelak. Keberuntungan besar tersebut telah dijanjikan oleh Allah seperti diterangkan dalam surat At Taubah:105, Al Jumu'ah:10 dan Al Qashash:77).

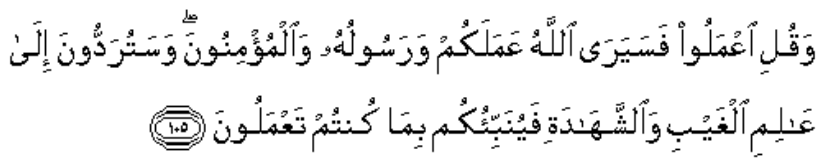

"Dan katakanlah: "Bekerjalah kamu, maka Allah dan Rasul-Nya serta orang-orang mu'min akan melihat pekerjaanmu itu, dan kamu akan dikembalikan kepada (Allah) Yang Mengetahui akan yang ghaib dan yang nyata, lalu diberitakan-Nya kepada kamu apa yang telah kamu kerjakan”. (QS 9 At Taubah:105)

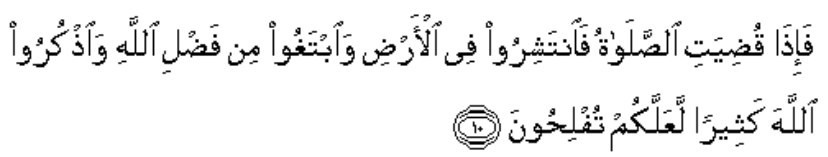

"Apabila telah ditunaikan sembahyang, maka bertebaranlah kamu di muka bumi; dan carilah karunia Allah dan ingatlah Allah banyak-banyak supaya kamu beruntung”. (QS 62 Al Jumu'ah:10)

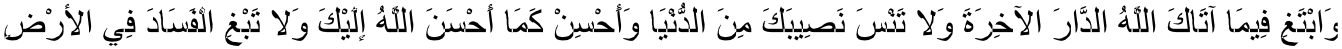

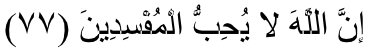

"Dan carilah pada apa yang telah dianugerahkan Allah kepadamu (kebahagiaan) negeri akhirat, dan janganlah kamu melupakan bagianmu dari (kenikmatan) duniawi dan berbuat baiklah (kepada orang lain) sebagaimana Allah telah berbuat baik kepadamu, dan janganlah kamu berbuat kerusakan di (muka) bumi. Sesungguhnya Allah tidak menyukai orang-orang yang berbuat kerusakan”(QS:28; Al Qashash:77)

Nafik (2010) mengatakan bahwa salah satu produk Bank Islam adalah pembiayaan. Pembiayaan yang disalurkan oleh bank Islam tidak semuanya harus dengan bagi hasil tetapi ada yang hanya memberikan pembiayaan tanpa meminta bagi hasil. Jenis pembiayaan tersebut digolongkan pinjaman dalam kebaikkan (qardul hasan) dan akan mendapat pembalasan yang berlipat ganda dari Allah, dasar hukumnya adalah sebagi berikut:

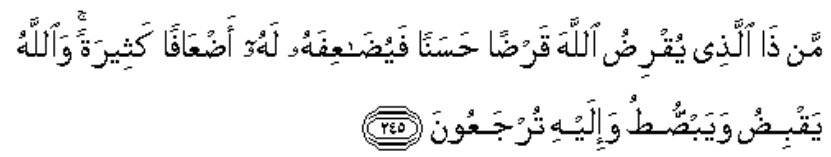

"Siapakah yang mau memberi pinjaman kepada Allah, pinjaman yang baik, maka Allah akan melipat gandakan pembayaran kepadanya dengan lipat ganda yang banyak. Dan Allah menyempitkan dan melapangkan (rezki) dan kepada-Nya-lah kamu dikembalikan." (Al Baqarah 245). 


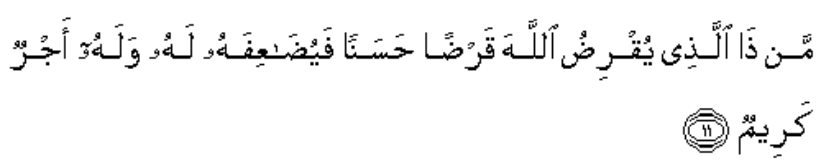

"Siapakah yang mau memberi pinjaman kepada Allah, pinjaman yang baik, maka Allah akan melipat gandakan pinjaman itu untuknya dan dia kan memperoleh pahala yang banyak." (Al Hadiid 11).

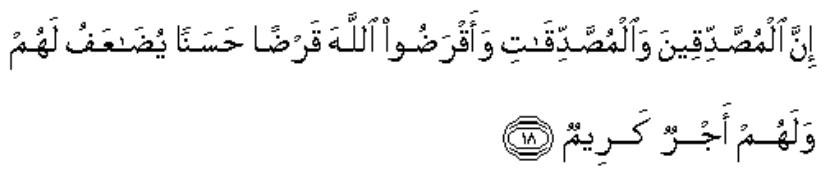

Pinjaman untuk kebaikan ini sangat dianjurkan dalam Islam, hal ini ditunjukkan oleh perintahnya dalam surat Al Hadiid ayat 11 diulangi kembali pada ayat 18:

"Sesungguhnya orang-orang yang bersedekah baik laki-laki maupun perempuan dan meminjamkan kepada Allah, pinjaman yang baik, niscaya akan dilipat gandakan (pembayarannya) kepada mereka dan bagi mereka memperoleh pahala yang banyak." (Al Hadiid 18).

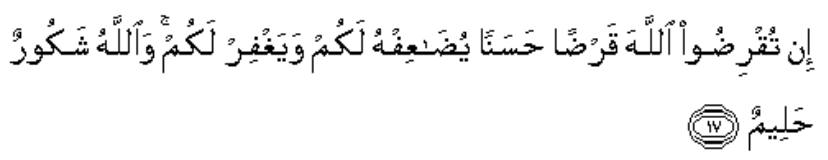

"Jika kamu meminjamkan kepada Allah, pinjaman yang baik, niscaya Allah melipat gandakan (pembalasannya) kepadamu dan mengampuni kamu. Dan Allah Maha Pembalas Jasa lagi Maha Penyantun." (At Taghaabun 17).

Nafik (2010) mengatakan bahwa kinerja bank Islam dapat dilihat dari hasil dalam menjalankan fungsinya sebagai lembaga intermediasi, lembaga bisnis dan investasi serta lembaga sosial. Kinerja bank Islam yang tidak kalah penting bahkan harus menjadi prioritas dibandingkan dengan kinerja di atas adalah komitmennya dalam memperdayakan perekonomian masyarakat khususnya masyarakat miskin dan pengusaha kecil. Pengusaha kecil yang selama tidak ditangani (tidak dijangkau) oleh bank konvesional karena dianggap tidak bankable merupakan tanggungjawab bank Islam. Mereka termasuk masyarakat yang termarginalkan oleh sistem ekonomi yang lebih mengedepankan maksimisasi keuntungan finansial dan cenderung mengabaikan kuntungan non finansial. Mereka lupa bahwa keuntungan non finansial itulah yang akan mendatangkan sustainable keuntungan finansial yang maksimum di masa akan datang.

\section{Konsep Pengembangan Model Fungsi Sosial Bisnis Islam, Khususnya Bank Syariah X Berdasarkan Maqashid Syariah}

Sesuai dengan misi Bank Syariah X yaitu: 1) Mewujudkan pertumbuhan dan keuntungan yang berkesinambungan, 2) Mengutamakan penghimpunan dana konsumer dan penyaluran pembiayaan pada segmen Usaha Mikro Kecil dan Menengah (UMKM), 3) Merekrut dan mengembangkan pegawai profesional dalam lingkungan kerja yang sehat, 4) Mengembangkan nilai - nilai syariah universal, dan 5) Menyelenggarakan operasional 
bank sesuai standar perbankan yang sehat, khususnya misi keempat Bank Syariah X, yaitu mengembangkan nilai-nilai syariah universal, maka Bank Syariah X mengeluarkan filosofi sebagai Value Driven Company yang secara terus menerus diimplementasikan dalam lingkungan kerja. Humanity sebagai bagian dari shared values, memiliki salah satu core behavior yaitu Social Responsibility yang berarti Bank Syariah X memiliki kepedulian terhadap lingkungan dan sosial tanpa mengabaikan tujuan perusahaan. Dalam implementasi pelaksanaan CSR, Bank Syariah X menjalin kerja sama dengan LAZNAS Bank Syariah X/Lembaga Mitra dalam penyaluran dana zakat perusahaan dan pelaksanaan program-program yang bersifat humanity. Acuan kerja pelaksanaan program CSR melalui Perjanjian Kerja Sama (PKS) Bank Syariah X dan LAZNAZ Bank Syariah X No. 12/410PKS/DIR; N0.09/001/LAZBANK SYARIAH X/DIR tanggal 12 November 2010 tentang Penyaluran Zakat dan Dana Program.

Bank Syariah X menyadari bahwa Tanggung Jawab Sosial Perusahaan (Corporate Social Responsibility/CSR) merupakan hal penting dalam mendukung tumbuh kembangnya Bank. Bank menempatkan CSR sebagai bagian program jangka panjang perusahaan. Bank dalam upaya mencapai sustainable business senantiasa berusaha memberikan kinerja yang optimal untuk para pemegang saham namun juga memikirkan bagaimana memberikan kontribusi secara maksimal dalam aspek sosial dan lingkungan.

Dalam pelaksanaan kegiatan CSR Bank menggunakan pendekatan keseimbangan profit, people dan planet yang lebih dikenal dengan tripple bottom lines. Bank tidak hanya semata-mata mengejar kepentingan ekonomi (profit) namun juga aspek sosial (people) dan lingkungan (planet). Bank berusaha mencapai keseimbangan "tripple bottom lines" dalam pencapaian tujuannya sehingga mampu memberikan nilai lebih kepada Stakeholders-nya.

Bank secara konsisten melaksanakan kegiatan fungsi sosial sebagai wujud kepedulian perusahaan sekaligus apresiasi kepada masyarakat yang telah memberikan kepercayaan dan dukungan atas proses bisnis perbankan syariah. Keberlangsungan bisnis bank tidak lepas dari partisipasi masyarakat dalam menyambut berbagai produk perbankan syariah dan layanan yang ditawarkan oleh bank.

Corporate Social Responsibility (CSR) merujuk pada semua hubungan yang terjadi antara perusahaan dan semua stakeholders, termasuk pelanggan, pegawai, komunitas, pemilik, pemerintah, supplier bahkan kompetitor. CSR merupakan konsep di mana Bank Syariah X secara sukarela menyumbangkan sesuatu ke arah masyarakat yang lebih baik dan lingkungan hidup yang lebih bersih. Kegiatan-kegiatan yang dijalankan Bank Syariah $\mathrm{X}$ di tahun 2009 terus diupayakan agar sesuai dengan konsep dasar CSR, yaitu membantu mengatasi atau mengurangi permasalahan yang terjadi di masyarakat, mengusahakan terjadinya perubahan perilaku masyarakat, dan mengupayakan pencapaian kesejahteraan kehidupan masyarakat.

Corporate Social Responsibility (CSR) yang dipandang dari perspektif Islam sebagai bentuk fungsi sosial, merujuk pada semua hubungan yang terjadi antara perusahaan dengan semua stakeholders, termasuk pelanggan, pegawai, komunitas, pemilik, pemerintah, supplier bahkan kompetitor. Fungsi sosial merupakan konsep di mana Bank Syariah $\mathrm{X}$ secara sukarela menyumbangkan sesuatu ke arah masyarakat yang lebih baik dan lingkungan hidup yang lebih bersih. Kegiatan-kegiatan yang dijalankan Bank Syariah X di tahun-tahun sebelumnya, terus diupayakan agar sesuai dengan konsep dasar fungsi sosial, yaitu membantu mengatasi atau mengurangi permasalahan yang terjadi di masyarakat, mengusahakan terjadinya perubahan perilaku masyarakat, dan mengupayakan pencapaian kesejahteraan kehidupan masyarakat. 
Adapun aktivitas fungsi sosial yang dilakukan Bank Syariah X bertujuan untuk:

1. Mendukung kesejahteraan masyarakat dan meningkatkan kualitas lingkungan.

2. Mendukung implementasi praktik bisnis yang transparan dan bertanggungjawab.

3. Membuat perubahan positif di tengah masyarakat, khususnya di lingkungan di mana Bank Syariah X beroperasi.

4. Membangun citra positif Bank Syariah X dalam benak masyarakat,dan menggalang dukungan masyarakat untuk tujuan bisnis Bank Syariah X.

5. Meningkatkan nilai brand Bank Syariah X dengan membangun reputasiyang baik.

6. Meningkatkan kesadaran publik tentang Bank Syariah X melalui kegiatan-kegiatan sosial.

Pelaksanaan program fungsi sosial di Bank Syariah X memiliki dua sumber dana, yakni Dana Kebajikan dan Dana Zakat, dengan uraian sebagai berikut:

1. Dana Kebajikan

Dana Kebajikan bersumber dari Denda, Pendapatan Non Halal dan Dana Sosial lainnya. Jenis kegiatan yang telah mendapat penyaluran Dana Kebajikan meliputi: Santunan anak yatim, pembangunan/renovasi masjid, khitanan massal, partisipasi kemanusiaan untuk Palestina, donor darah, beasiswa, iB CSR, pelatihan dakwah, pembangunan asrama rumah asuh, operasi bibir sumbing, bakti sosial, pengadaan perpustakaan anak yatim, korban gempa Tasikmalaya dan Sumatera serta pembinaan pedagang mikro.

2. Dana Zakat

Dana Zakat bersumber dari zakat perusahaan (Bank Syariah X), zakat nasabah dan umum, serta zakat pegawai Bank Syariah X. Penyaluran Dana Zakat dilaksanakan (bersinergi) dengan LAZNAS Bank Syariah X dan penyalurannya dilakukan melalui program yang berdaya guna dan bermanfaat yakni Mitra Umat, Didik Umat dan Simpati Umat kepada 14.582 orang (mustahikin).

\section{Praktek Pengembangan Model Fungsi Sosial Bisnis Islam Berdasarkan Maqashid Syariah pada Bank Syariah X di Surabaya}

Bank Syariah X meyakini bahwa kinerja bank harus memiliki dampak positif terhadap peningkatan kesejahteraan masyarakat. Peningkatan kesejahteraan masyarakat pada akhirnya akan mendukung pengembangan bisnis Bank Syariah X secara berkelanjutan.

Menurut Ratnasari (2014), kemaslahatan merupakan tujuan Syari'at (MaqashiduTasyri'), dalam rangka memelihara dan melindungi al-Kulliyatul-Khams (lima hal yang bersifat umum, menyeluruh). Adapun al-Kulliyatul-Khams adalah: Kemaslahatan itu kembali kepada pemeliharaan pokok-pokok yang lima (al-muhafazhah 'ala al-kulliyat al-khams), yang seringkali disebut dengan maqashid syari'ah, terdiri atas:

1. Hifdhud-din, terjaminnya hak atas tegaknya agama dan kebebasan beragama. Hal ini terkait dengan prinsip "tiada paksaan untuk memasuki suatu agama” (QS. al-Baqarah: 256). Agama diajarkan kepada manusia dengan perantara para Nabi dan Rasul. Islam adalah agama samawi terakhir yang disampaikan oleh Nabi Muhammad saw sebagai panduan hidup kaum muslim dan umat manusia lainnya untuk memecahkan permasalahan hidup.

2. Hifdhun-nafs, terjaminnya perlindungan hak hidup dan jiwa manusia. Jiwa adalah alam sederhana yang tidak terformulasi dari berbagai unsur (materi) sehingga tidak mengalami kehancuran sebagaimana benda (Salim, 2013). 
3. Hifdhun-nasl, terjaminnya hak atas pengembangan jenis dan keturunan. Islam adalah agama yang mengatur kehidupan dari segala aspek baik spiritual maupun material termasuk ekonomi dan keseimbangan antara keduanya. al-Qur'an (QS. al-Baqarah: 233) mengatur kesehatan dan kesejahteraan fisik keluarga. Islampun tidak membatasi bagi ummatnya untuk memiliki keturunan.

4. Hifdhul- 'aql, terjaminnya hak atas pengembangan akal dan pemikiran yang sehat. Makna al- "aql adalah "fahima wa tadabbaro" yang berarti paham (tahu, mengerti) dan memikirkan (menimbang), sehingga artinya adalah kemampuan memahami dan memikirkan sesuatu (ungkapan, penjelasan, fenomena, dan lain-lain) yang ditangkap oleh panca indera (Salim, 2013). Termasuk disini, hak atas keleluasaan berfikir dan berpendapat, hak atas pendidikan dan pengajaran.

5. Hifdhul-maal, terjaminnya perlindungan hak atau pemilikan harta benda. Termasuk dalam kategori ini, hak atas kebebasan bekerja, dan mendapatkan pekerjaan, hak mengelola dan mengeksploitasi sumber daya alam, dan hak atas pemilikan harta kekayaan. Namun, karena al-maal dalam bahasa Arab berarti emas, perak, dan hewan ternak, sedangkan menurut terminologi syariah berarti segala sesuatu yang memiliki nilai dan boleh dimanfaatkan serta kepemilikannya diperoleh dengan cara yang sesuai syariah, sebagaimana tercantum dalam al-Qur'an dalam QS. al-Hadiid: 5-7 (Salim, 2013).

Beberapa kegiatan fungsi sosial yang dilakukan oleh Bank Syariah X kepada warga masyarakat antara lain:

1. Bank Syariah X memberikan donasi berupa dana untuk renovasi masjid atau mushalla sebagai bentuk perbaikan sarana umum/publik

2. Bank Syariah $X$ memberikan santunan berupa beasiswa dan uang untuk kebutuhan sehari-hari bagi anak yatim agar dapat mengentaskan kebodohan yang terjadi pada masyarakat miskin

3. Bank Syariah X mendirikan Bank Syariah X-Care untuk 1000 anak korban letusan merapi

4. Bank Syariah X memberikan bantuan beberapa ekor kambing etawa kepada Ketua Kelompok Peternakan Kambing Etawa dalam rangka memperbaiki perekonomian masyarakat

5. Bank Syariah X memberikan pinjaman modal tanpa margin kepada masyarakat

Untuk mewujudkan peningkatan kesejahteraan masyarakat pada akhirnya akan mendukung pengembangan bisnis Bank Syariah X secara berkelanjutan berdasarkan fungsi maqashid syari'ah, maka Bank Syariah X melakukan berbagai aktifitas sosial yang didasarkan pada prinsip maqashid syari'ah yang dirangkum dalam Tabel 1. 
Tabel 1. Aktivitas Fungsi Sosial Bank Syariah X

\begin{tabular}{|c|c|}
\hline $\begin{array}{c}\text { Jenis } \\
\text { Maqashid } \\
\text { Syari'ah }\end{array}$ & Aktivitas Fungsi Sosial \\
\hline Hifdhud-din & $\begin{array}{l}\text { 1. Program bina lingkungan bidang keagamaan } \\
\text { Program CSR untuk bidang sosial, budaya, keagamaan yang diwujudkan dalam } \\
\text { bentuk santunan dhuafa, santunan Ramadhan, dan program-program lainnya. } \\
\text { 2. Program bina lingkungan bidang sarana umum } \\
\text { Program CSR untuk sarana umum diwujudkan dalam bentuk bantuan pembangunan } \\
\text { dan renovasi masjid dan madarasah, bantuan sarana umum dan program-program } \\
\text { lainnya. }\end{array}$ \\
\hline Hifdhun-nafs & $\begin{array}{l}\text { Program Sosial/Budaya } \\
\text { Dilaksanakan melalui Program Simpati Umat dalam berbagai kegiatan antara lain } \\
\text { pemberian bantuan kepada korban bencana, distribusi hewan kurban, pemberian } \\
\text { bantuan kesehatan, pembangunan masjid dan fasilitas publik lainnya maupun santunan } \\
\text { kepada dhuafa atau yatim piatu. }\end{array}$ \\
\hline Hifdhun-nasl & $\begin{array}{l}\text { Program bina lingkungan bidang kesehatan masyarakat dan lingkungan } \\
\text { Bank Syariah X berkomitmen untuk berpartisipasi dalam melaksanakan program } \\
\text { perbaikan kesehatan. Berbagai program yang dimiliki Bank Syariah X merupakan } \\
\text { program yang menyentuk langsung kepedulian terhadap masyarakat. Program- } \\
\text { program yang dilakukan Bank Syariah X di bidang perbaikan kesehatan antara lain: } \\
\text { pelaksanaan donor darah, operasi bibir sumbing untuk anak yatim, khitanan massal } \\
\text { dan program-program lainnya. Sedangkan bidang pelestarian lingkungan dilaksanakan } \\
\text { antara lain penanaman pohon mangrove. Kegiatan dilaksanakan baik oleh Kantor } \\
\text { Pusat Bank di Jakarta maupun Kantor Cabang yang tersebar di berbagai daerah. }\end{array}$ \\
\hline Hifdhul-'aql & $\begin{array}{l}\text { 1. Program bina lingkungan bidang pendidikan dan pelatihan } \\
\text { Bank Syariah X berkomitmen untuk berpartisipasi dalam melaksanakan program } \\
\text { pengembangan pendidikan sebagai salah satu bentuk sumbangsih Bank Syariah X } \\
\text { untuk pengembangan Indonesia. Program difokuskan pada peningkatan kualitas } \\
\text { pendidikan, yang diwujudkan dalam bentuk pemberian beasiswa kepada siswa } \\
\text { dari keluarga kurang mampu. Program Pengembangan Pendidikan dilaksanakan } \\
\text { melalui Program Didik Umat yang merupakan salah satu program pengembangan } \\
\text { sumber daya manusia. Sasaran dari program ini adalah pemberdayaan pendidikan } \\
\text { mulai dari tingkat SD, SMP, SMU/K dan perguruan tinggi. Kegiatan dilaksanakan } \\
\text { secara menyeluruh baik di lingkungan Kantor Pusat Bank di Jakarta maupun } \\
\text { kantor cabang di seluruh pelosok negeri. } \\
\text { 2. Program pelestarian lingkungan } \\
\text { Persoalan utama yang dihadapi dalam upaya melestarikan lingkungan, khususnya } \\
\text { sumber daya hutan adalah terjadinya degradasi hutan dan lahan yang disebabkan } \\
\text { oleh pembalakan liar, perambahan hutan dan pengurangan kawasan hutan } \\
\text { (deforestasi) untuk kepentingan pembangunan lain yang berakibat terjadinya } \\
\text { bencana banjir, kekeringan dan tanah longsor maupun kontribusi yang nyata } \\
\text { terhadap pemanasan global. }\end{array}$ \\
\hline
\end{tabular}




\begin{tabular}{|c|c|}
\hline $\begin{array}{c}\text { Jenis } \\
\text { Maqashid } \\
\text { Syari'ah }\end{array}$ & Aktivitas Fungsi Sosial \\
\hline Hifdhul-'aql & $\begin{array}{l}\text { Upaya memulihkan kerusakan hutan dan lahan dilaksanakan dengan merehabilitasi } \\
\text { kembali hutan rusak dan lahan kritis DAS melalui kegiatan menanam, baik secara } \\
\text { keproyekan (Reboisasi/Gerhan) maupun gerakan menanam secara massal oleh } \\
\text { masyarakat luas sebagai bentuk kesadaran dan kepedulian terhadap upaya pemulihan } \\
\text { kerusakan sumber daya hutan. Peduli terhadap hal tersebut, Bank Syariah X } \\
\text { mengkampanyekan kepedulian terhadap pelestarian lingkungan. Melalui program } \\
\text { Bank Syariah X Peduli Penghijauan, Bank Syariah X melakukan gerakan penanaman } \\
\text { pohon. Kegiatan ini dicanangkan secara resmi oleh jajaran Direksi pada bulan April } \\
\text { 2009. Bank Syariah X Peduli Penghijauan melibatkan Direksi dan pegawai Bank } \\
\text { Syariah X, direalisasikan dalam bentuk penanaman bibit pohon serta perbaikan taman } \\
\text { kota. Melalui gerakan Bank Syariah X Peduli Penghijauan, Bank Syariah X juga ingin } \\
\text { mengajak stakeholders untuk peduli dan melestarikan lingkungan melalui program } \\
\text { nyata. Selain mengadakan program Bank Syariah X Peduli Penghijauan, Bank Syariah } \\
\text { X juga melakukan berbagai program kampanye lainnya, antara lain gerakan hemat } \\
\text { listrik, hemat kertas, hemat air dan hemat bahan bakar minyak. Kampanye dilakukan } \\
\text { pada seluruh karyawan dalam unit kerja dengan berbagai media, antara lain poster, } \\
\text { banner, spanduk dan leaflet. }\end{array}$ \\
\hline Hifdhul-maal & $\begin{array}{l}\text { Program kemitraan } \\
\text { Pelaksanaan fungsi sosial bidang pengembangan ekonomi umat bertujuan untuk } \\
\text { menciptakan kemandirian masyarakat dalam mencapai peningkatan kesejahteraan } \\
\text { dalam jangka panjang. Bank Syariah X berkomitmen untuk berpartisipasi dalam } \\
\text { menjalin kemitraan dan mengembangkan sektor ekonomi masyarakat sekitar. Wujud } \\
\text { kepedulian Bank Syariah X tersebut dilakukan dalam bentuk Program Mitra Umat } \\
\text { yakni pemberdayaan sektor ekonomi mikro dengan skema qardhul hasan. Sasaran } \\
\text { program ini supaya para mustahik yang menerima dana akan berubah menjadi muzaki. } \\
\text { Bantuan diberikan dalam bentuk pemberdayaan masyarakat dalam kegiatan kegiatan } \\
\text { ekonomi, meliputi budidaya jamur, budi daya kelinci dan pinjaman modal usaha } \\
\text { mikro. Sampai saat ini pengembangan dan perbaikan atas program ini terus dilakukan. } \\
\text { Program fungsi sosial yang lain dalam bidang ini diwujudkan dalam pemberian } \\
\text { bantuan permodalan, sarana kerja dan sebagainya. }\end{array}$ \\
\hline
\end{tabular}

Sumber: data internal Bank Syariah X

Laznas Bank Syariah X mengklaim telah menyalurkan dana untuk kegiatan fungsi sosial dan dana zakat, infak serta sedekah hingga Oktober 2013 sebesar Rp25,5 miliar. Direktur Laznas Bank Syariah X, mengatakan dana tersebut disalurkan dalam bentuk program Mitra Umat (pemberdayaan ekonomi sebesar Rp 6,4 miliar), Didik Umat sebesar Rp7,4 miliar (bidang pendidikan), dan Simpati Umat (11,7 miliar). Total dana yang dianggarkan, akan tersalurkan selama 2013 sebesar Rp 40 miliar. Penyaluran tersebut berdasarkan program permanen atau reguler maupun yang bersifat temporer. Program permanen atau reguler merupakan program yang berjalan secara rutin sepanjang tahun. Sementara program temporer bergantung permohonan serta situasi dan kondisi yang membutuhkan bantuan penyaluran, seperti bencana alam dan sosial, pengobatan massal, dan bantuan dakwah.

Program Mitra Umat bertujuan mengangkat pemberdayaan ekonomi kaum lemah, seperti pedagang bakso dan lain-lain. Sementara program Didik Umat bertujuan pemberdayaan di bidang pendidikan, baik infrastruktur pendidikan maupun beasiswa. 
Untuk program kesehatan, Bank Syariah X mempunyai program Dokter Keluarga Sehat dan Warung Gizi Balita. Program kesehatan ini berupa pengobatan gratis yang ditujukan kepada masyarakat tak mampu. Sumber dana untuk menjalankan berbagai program Laznas Bank Syariah X di antaranya berasal dari zakat, infak, dan sedekah (ZIS), baik dari perusahaan, karyawan, nasabah, dan donatur umum. Terdapat dana sebesar Rp500 juta rupiah setiap bulan yang berasal hanya dari para karyawan Bank Syariah X (www. Bank Syariah X.co.id).

\section{Dampak Pengembangan Model Fungsi Sosial Bisnis Islam Berdasarkan Maqashid Syariah}

Bank Syariah Mandiri dalam menjalankan fungsi sosial menunjukkan komitmen dan keberpihakannya terhadap ekonomi lemah, pihak yang kurang beruntung dan berekonomi. Dengan demikian kualitas hidup warga masyarakat di sekitar lokasi Bank Syariah $\mathrm{X}$ dapat lebih baik. Hal ini dibuktikan dari hasil penelitian yang dilakukan Ryandono (2010) menunjukkan bahwa penghimpunan dana masyarakat Bank Syariah X berperan dan berpengaruh positif terhadap penyaluran dana. Penyaluran dana berpengaruh positif terhadap kinerja sosial, salah satunya adalah fungsi sosial.

Kebijakan Bank Syariah X yang menawarkan produk penghimpunan dananya yang menggunakan aqad titipan (wadi'ah) dan bagi hasil (mudharabah) telah mampu meningkatkan kepercayaan masyarakat untuk menempatkan dananya di Bank Syariah X. Dana masyarakat mayoritas terkumpul dalam aqad mudharabah, sehingga pihak Bank Syariah X lebih leluasa dalam menyalurkannya menjadi pembiayaan. Pembiayaan yang disalurkan tersebut tidak semata-mata untuk memperoleh keuntungan melainkan juga bertujuan sosial. Hal ini dapat dilihat makin menurunnya pembiayaan yang berbasiskan pendapatan tetap (murabahah, istishna, dan ijarah) dan makin meningkatnya pembiayaan berbasiskan bagi hasil (mudharabah dan musyarakah) dan berprinsipkan kebaikan (qardhul hasan).

Pembiayaan yang berbasiskan bagi hasil dan berprinsipkan kebaikan yang makin meningkat maka akan makin meningkatkan pemberdayaan ekonomi masyarakat. Makin berdayanya ekonomi masyarakat maka akan makin meningkatkan dana masyarakat yang dihimpun oleh Bank Syariah X, kemudian akan meningkatkan pembiayaan yang disalurkan dan siklus ini terus berputar dengan putaran yang makin besar. Dampaknya, adalah meningkatnya kinerja sosial (fungsi sosial) selain kinerja tijarah (bisnis). Dengan demikian, sebuah Bank Islam jika dikatakan sukses, apabila tidak hanya mampu mencapai kinerja tijarah (bisnis) yang tinggi tetapi juga harus memiliki kinerja sosial seperti menjalankan fungsi sosial yang tinggi pula. Aktifitas fungsi sosial yang tinggi, akan mampu meningkatkan kepercayaan dan komitmen masyarakat untuk menggunakan jasa dan memilih produk yang ditawarkan pihak Bank Syariah X. Dampaknya, adalah meningkatnya dana yang terhimpun kemudian akan meningkatkan kemampuan penyaluran dana Bank Syariah X. Kemudian, akan meningkatkan likuiditas, solvabilitas, dan profitabilitasnya. Tingkat keuntungan yang meningkat memungkinkan Bank Syariah $\mathrm{X}$ untuk meningkatkan gaji, upah, bonus dan tunjangan lainnya. Pendapatan yang makin tinggi maka akan mendorong produktiftasnya dan rata-rata pendapatan per kapitanya juga akan meningkat.

Selain fungsi sosial yang berdampak pada peningkatan kualitas hidup masyarakat di sekitar Bank Syariah X dan juga berdampak kepada para karyawan Bank Syariah X, Ratnasari (2012) menyatakan bahwa fungsi sosial mampu membuat perusahaan memiliki 
citra yang positif di mata konsumen dan bagian masyarakat lainnya, selain itu Ancok (2005) juga menyatakan bahwa manfaat pelaksanaan program fungsi sosial bagi bank atau perusahaan salah satunya yaitu untuk memelihara dan meningkatkan citra perusahaan. Saputri (2010) juga menambahkan bahwa perusahaan yang menjalankan tanggung jawab sosialnya secara konsisten akan mendapatkan dukungan yang luas dari komunitas yang merasakan manfaat dari berbagai aktivitas yang dijalankannya. CSR akan meningkatkan citra perusahaan dan dalam waktu yang panjang akan terakumulasi menjadi reputasi perusahaan.

Selain itu menurut survei yang dilakukan oleh Environics International (Toronto), Conference Board (New York) dan Prince of Wales Business Leader Forum (London) Anindya (2012), bahwa 60\% dari 25.000 responden di 23 negara berpendapat bahwa tanggung jawab sosial perusahaan merupakan salah satu faktor pembentuk citra baik perusahaan. Lebih lanjut, responden selaku konsumen perusahaan bersikap terhadap perusahaan yang tidak menjalankan CSR adalah ingin "menghukum" (40\%) dan 50\% tidak akan membeli produk dari perusahaan yang bersangkutan atau bicara kepada orang lain tentang kekurangan perusahaan tersebut. Demikian juga sebaliknya, perusahaan yang tidak mengimplementasikan fungsi sosial akan mendapat penilaian negatif dari publik atau nasabah.

Hasil penelitian yang telah dilakukan oleh Anindya (2012) menunjukkan terdapat pengaruh yang signifikan fungsi sosial terhadap citra Bank Syariah X di Surabaya dengan nilai signifikansi 0,026 . Hal ini menunjukkan bahwa hipotesis kedua dalam penelitian ini dapat diterima, yang artinya bahwa fungsi sosial berpengaruh secara signifikan terhadap citra.

Berdasarkan fakta di lapangan, citra positif yang di miliki Bank Syariah X terbentuk karena adanya aktivitas fungsi sosial yang dilakukan oleh Bank Syariah X sebagai bentuk pertanggung jawaban Bank Syariah X terhadap Allah SWT, masyarakat, dan lingkungan sekitar. Nasabah memandang bahwa dengan adanya kegiatan fungsi sosial tersebut, Bank Syariah X telah menunjukkan bentuk pertanggungjawabannya sebagai hamba Allah SWT yang telah memiliki harta berkecukupan untuk bersedia berbagi kebahagiaan dengan orang lain agar kehidupannya bisa mencapai idrak shilah billah (kedekatan hubungannya dengan Allah SWT karena mendapatkan ridho-Nya), sehingga nasabah akhirnya memiliki pandangan yang positif terhadap Bank Syariah X dan pada akhirnya membentuk citra positif untuk Bank Syariah X.

Namun, yang perlu diperhatikan oleh pihak manajemen Bank Syariah Mandiri, adalah dengan mengacu terhadap pendapat yang disampaikan oleh Anindya (2012) yang menyatakan bahwa fungsi sosial akan mampu membuat perusahaan memiliki citra yang positif sehingga meningkatkan minat konsumen untuk melakukan pembelian terhadap produk perusahaan tersebut. Pada hakikatnya secara fitrah manusia adalah makhluk sosial dan makhluk berakal serta bermoral, sehingga mereka cenderung mencari segala sesuatu yang memiliki kesamaan visi dengan dirinya. Sahabat Abdullah bin 'Abbas r.a pun pernah berkata bahwasanya "Hati itu diciptakan dengan tabiat mencintai orang yang berbuat baik dan membenci sebaliknya". Hal tersebut tentu akan mendatangkan rezeki yang barokah bagi perusahaan dan konsumen. Perusahaan akan mendapatkan profit sekaligus benefit dengan dipercaya produknya (Brand Loyalty) dan perusahaannya (Company Loyalty) oleh konsumen, lalu konsumen serta masyarakat dapat menikmati dan merasakan fasilitas umum dari program fungsi sosial tersebut. 
Sebagaimana dinyatakan oleh Ryandono (2010), bahwa Bank Syariah X sebagai bagian dari Bank Islam, memiliki peran tinggi dalam menjalankan fungsi sosialnya untuk menciptakan keadilan dan kesejahteraan sosial khususnya masyarakat eksternal bank. Fungi sosial lebih ditujukan untuk masyarakat eksternal lingkungan Bank Syariah X.

Oleh karena itu, pihak manajemen Bank Syariah X jangan sampai untuk pembiayaan UKM (Usaha Kecil dan Menengah), yang lebih kental untuk keperluan pemasarannya (menyelenggarakan event untuk pameran UKM, dibiayai untuk dapat pameran di suatu tempat, yang mungkin pernah dibiayai bisa sukses, namun lebh banyak untuk promosi). Harusnya fungsi sosial digunakan untuk kepentingan lingkungan sosial dari bank tersebut, harusnya dimana bank tersebut berada, stakeholder jadi obyek dari fungsi sosial tersebut. Sebagaimana hadits: bersedekahlah kepada orang terdekat kalian. yang dimulai dari kerabat dan tetangga terlebih dulu. Oleh karena itu, aturan dari Bank Indonesia harusnya jelas, agar pihak bank yang melakukan fungsi sosial tidak cenderung menjadi promosi untuk keperluan pemerekan (branding).

\section{SIMPULAN DAN SARAN}

\section{Simpulan}

Saran yang dapat diambil dari hasil penelitian ini sebagai berikut:

1. Konsep pengembangan model fungsi sosial bisnis Islam, khususnya Bank Syariah $\mathrm{X}$ berdasarkan maqashid syariah telah memiliki peran penting dalam menciptakan keadilan dan kesejahteraan berdasarkan prinsip maqashid syari'ah khususnya masyarakat eksternal Bank Syariah X.

2. Praktek pengembangan model fungsi sosial bisnis Islam berdasarkan maqashid syariah pada Bank Syariah X telah memiliki peran besar dalam hal memerangi dan mengurangi disorientasi dalam beragama (hifdhud-din), terpeliharanya dari kebodohan (hifdhul- 'aqal), terjauhkannya dari kemiskinan (hifdhul maal), memiliki keturunan yang baik (hifdhun-nasl), dan terpeliharanya jiwa yang sehat (hifhdunnafs).

3. Dampak pengembangan model fungsi sosial bisnis Islam berdasarkan maqashid syariah tidak hanya pada peningkatan kualitas hidup warga sekitar lokasi Bank Syariah X yang memiliki tingkat perekonomian lemah, namun juga memberikan dampak positif kepada citra Bank Syariah X di benak nasabah dan bagian masyarakat lainnya.

\section{Saran}

Saran yang dapat diberikan berdasarkan hasil penelitian ini sebagai berikut:

1. Bagi pihak manajemen Bank Syariah X, hendaknya menjadikan aktifitas fungsi sosial dipertahankan dan bahkan ditingkatkan baik dari kualitas maupun kuantitas pemberian bantuan, namun tidak berhenti sampai disitu, seharusnya pihak Bank Syariah X yang melakukan aktifitas fungsi sosial senantiasa melakukan kontrol sehingga dapat diamati perubahan-perubahan yang nampak sebelum dan sesudah disalurkannya bantuan dari aktifitas fungsi sosial tersebut.

2. Pihak manajemen Bank Syariah X pihak manajemen Bank Syariah X jangan sampai untuk pembiayaan UKM (Usaha Kecil dan Menengah), yang lebih kental untuk keperluan pemasarannya (menyelenggarakan event untuk pameran UKM, dibiayai 
untuk dapat pameran di suatu tempat, yang mungkin pernah dibiayai bisa sukses, namun lebih banyak untuk promosi). Harusnya fungsi sosial digunakan untuk kepentingan lingkungan sosial dari bank tersebut, harusnya dimana bank tersebut berada, stakeholder jadi obyek dari fungsi sosial tersebut.

3. Perlunya aturan dari Bank Indonesia harusnya jelas, agar pihak bank syariah yang melakukan fungsi sosial tidak cenderung menjadi promosi untuk keperluan pemerekan (branding).

\section{REFERENSI}

Anindya, Tiara. 2012. Pengaruh Fungsi Sosial terhadap Citra Perusahaan dan Istiqomah pada Nasabah Bank Syariah Mandiri di Surabaya.

Depag RI, Al Qur'an dan Terjemahannya Al-Jumanatul 'Ali, 2004, J-ART, Bandung.

Muslim, Aziz. 2009. Metodologi Pengembangan Masyarakat. Jogjakarta. Penerbit Teras.

Gym AA dan Ippho Santoso. 2006. Qalbu Marketing: 7 Kunci Menuju Kemenangan. Kelompok Mizan. Jakarta.

Prastowo, Joko dan Miftachul Huda. 2011. Corporate Social Responsibility: Kunci Meraih Kemuliaan Bisnis. Jogjakarta. Samudra Biru.

Rahman, Shafiqur. 2011. Evaluation of Definitions: Ten Dimensions of Corporate Social Responsibility. World Review of Business Research. Vol. 1 (1), pp. 166-176.

Ratnasari, Ririn Tri. 2014. Pengaruh Kepemimpinan Islam dan Pemasaran Internal terhadap Kinerja Pemasaran dan Kesejahteraan Karyawan Bank Islam di Jawa Timur. Disertasi tidak diterbitkan. Program Pasca Sarjana. Universitas Airlangga. Surabaya.

Ryandono, Muhammad Nafik. 2010. Peran dan Pengaruh Penghimpunan Dana terhadap Penyaluran Dana dan Faktor Kinerja Bank serta Kesejahteraan Karyawan Bank Islam di Indonesia. Disertasi tidak diterbitkan. Program Pasca Sarjana. Universitas Airlangga. Surabaya.

Sholihin, Muhammad, 2010, Hebatnya Marketing Muhammad, Yogyakarta: Cemerlang Publishing.

Solimun. 2002. Structural Equation Modelling Lisrel dan Amos. Fakultas MIPA Universitas Brawijaya. Malang.

Wahyudi, Isa dan Busyra Azheri. 2011. Corporate Social Responsibility: Prinsip, Pengaturan, dan Implementasi. Malang. Setara Press.

Wibisono, Yusuf. 2007. Membedah Konsep dan Aplikasi Corporate Social Responsibility. Gresik. Fascho Publisher.

www.syariahmandiri.co.id 